\title{
Holocene Paleohydrology of the Tropical Andes from Lake Records
}

\author{
M.B. Abbott \\ G.O. Seltzer \\ K.R. Kelts \\ J. Southon
}

March 3, 1997

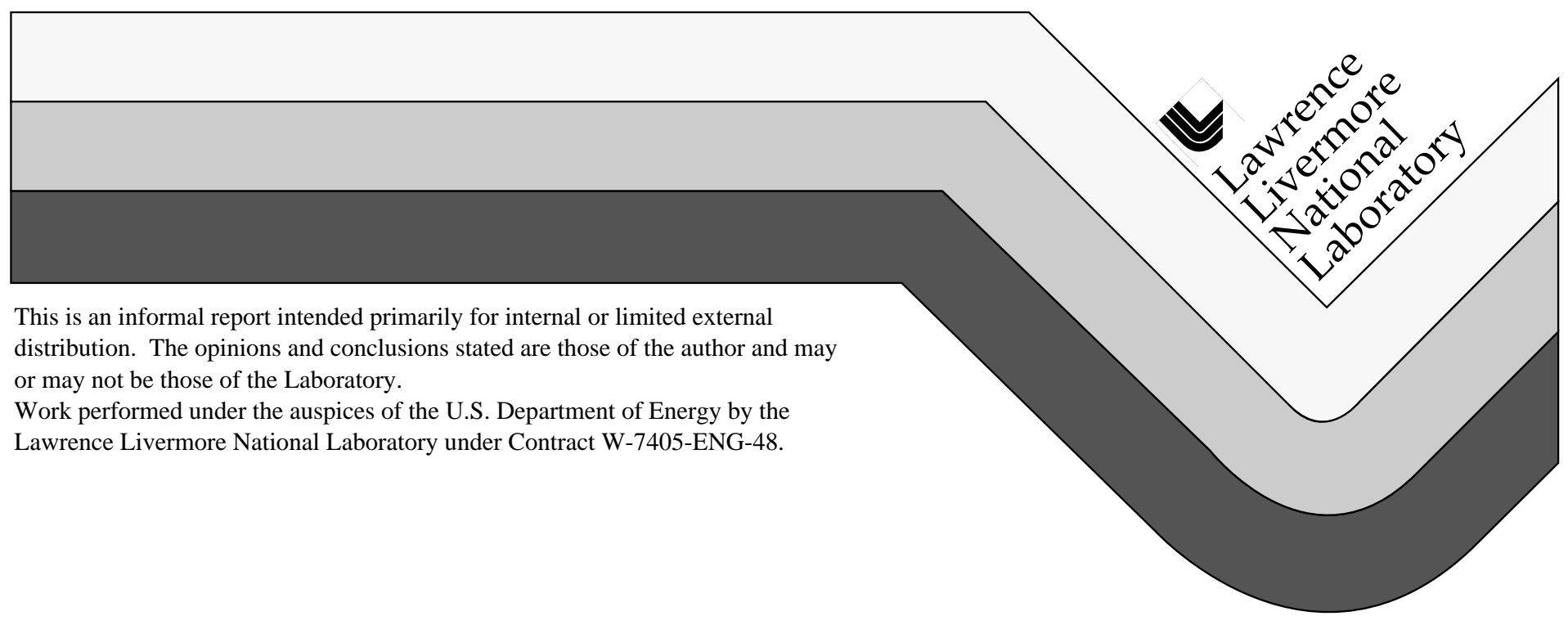




\section{DISCLAIMER}

This document was prepared as an account of work sponsored by an agency of the United States Government. Neither the United States Government nor the University of California nor any of their employees, makes any warranty, express or implied, or assumes any legal liability or responsibility for the accuracy, completeness, or usefulness of any information, apparatus, product, or process disclosed, or represents that its use would not infringe privately owned rights. Reference herein to any specific commercial product, process, or service by trade name, trademark, manufacturer, or otherwise, does not necessarily constitute or imply its endorsement, recommendation, or favoring by the United States Government or the University of California. The views and opinions of authors expressed herein do not necessarily state or reflect those of the United States Government or the University of California, and shall not be used for advertising or product endorsement purposes.

This report has been reproduced directly from the best available copy.

Available to DOE and DOE contractors from the Office of Scientific and Technical Information P.O. Box 62, Oak Ridge, TN 37831

Prices available from (423) 576-8401

Available to the public from the National Technical Information Service

U.S. Department of Commerce 5285 Port Royal Rd. Springfield, VA 22161 


\title{
Holocene Paleohydrology of the Tropical Andes from Lake Records
}

\author{
MARK B. ABbotT \\ Department of Geosciences, Morrill Science Center, University of Massachusetts, Box 35820, Amherst, Massachusetts 01003-5820 \\ GEOFFREY O. SELTZER \\ Department of Earth Sciences, Heroy Geology Laboratory, Syracuse University, Syracuse, New York 13244-1070 \\ KERRY R. KELTS \\ Limnological Research Center, University of Minnesota, 220 Pillsbury Hall. 310 Pillsbury Dr SE, Minneapolis, Minnesota 55455
}

AND

JoHN SOUTHON

Center for Accelerator Mass Spectrometry, Lawrence Livermore National Laboratory, P.O. Box 808, L-397, Livermore, California 94551-9900

\begin{abstract}
Two century-scale time series in northern Bolivia constrain the ages of abrupt changes in the physical, geochemical, and biological characteristics of sediments obtained from lakes that formed during deglaciation from the late Pleistocene glacial maximum. The watersheds of Laguna Viscachani $\left(16^{\circ} 12^{\prime} \mathrm{S}, 68^{\circ} 07^{\prime} \mathrm{W}, 3780 \mathrm{~m}\right)$ and Lago Taypi Chaka Kkota (16 $\left.13^{\circ} \mathrm{S}, 68^{\circ} 21^{\prime} \mathrm{W}, 4300 \mathrm{~m}\right)$, located on the eastern and western slopes of the Cordillera Real, respectively, contain small cirque glaciers. A high-resolution chronology of the lake sediments is provided by $23 \mathrm{AMS}{ }^{14} \mathrm{C}$ dates of discrete macrofossils. Late Pleistocene glaciers retreated rapidly, exposing the lake basins between 10,700 and $9700{ }^{14} \mathrm{C}$ yr B.P. The sedimentary facies suggest that after $8900{ }^{14} \mathrm{C}$ yr B.P. glaciers were absent from the watersheds and remained so during the middle Holocene. An increase in the precipitation-evaporation balance is indicated above unconformities dated to $\sim 2300{ }^{14} \mathrm{C}$ yr B.P. in both Lago Taypi Chaka Kkota and Laguna Viscachani. An abrupt increase in sediment accumulation rates after $1400{ }^{14} \mathrm{C}$ yr B.F. signals the onset of Neoglaciation. A possible link exists between the observed millennial-scale shifts in the regional precipitation-evaporation balance and seasonal shifts in tropical insolation. 01997 Univeraity of wechingron.
\end{abstract}

\section{INTRODUCTION}

Lake-sediment records from both sides of the Cordillera Real, Bolivia. were analyzed to investigate the Holocene environmental dynamics of the Bolivian Andes (Fig. 1). These time series also extend the 3500-yr record of changes in the precipitation-evaporation balance for the region established by dating water-level fluctuations in Lake Titicaca (Abbott et al., in press; Binford et al., in press). The shallow southern basin of Lake Titicaca (Lago Wiñaymarka) contains an incomplete Holocene record because it was almost completely desiccated prior to about $3500{ }^{14} \mathrm{C}$ yr B.P. (Wirrmann et al., 1990; Wirrmann and Mourguiart, 1995; Abbott, 1995). Also, all of the closed basin lakes in the cordillera are ephemeral lakes lacking a complete Holocene record that extends through the proposed mid-Holocene dry phase. Therefore, we targeted glacier-fed lakes with a positive water balance to obtain continuous Holocene paleoclimate sequences. Although the glacial lakes in this study maintain overflowing stages throughout the dry season (May-November), the erosion and deposition histories of Lago Taypi Chaka Kkota and Laguna Viscachani provide strong evidence for a dry middle Holocene. We suggest that cirque glaciers were absent from the watersheds during the middle Holocene, and without ice to provide a meltwater buffer during the dry season, a lake would have been seasonally lower or become desiccated. The absence of a meltwater buffer also rendered these high-altitude lake systems more susceptible to annual to century-scale droughts during the middle Holocene.

Previous water-level studies in Lake Titicaca imply a negative trend in the regional precipitation-evaporation balance from the latest Pleistocene to the middle Holocene (Servant and Fontes, 1978; Wirmann and De Oliveira Almeida, 1987; Mourguiart, 1990). Studies of glacier retreat and higher snowlines for this period provide further evidence supporting a negative water balance in the region (Gouze et al., 1986; Seltzer, 1992).

Here we present new proxy climate data from two sites in tropical South America indicating a middle Holocene dry 


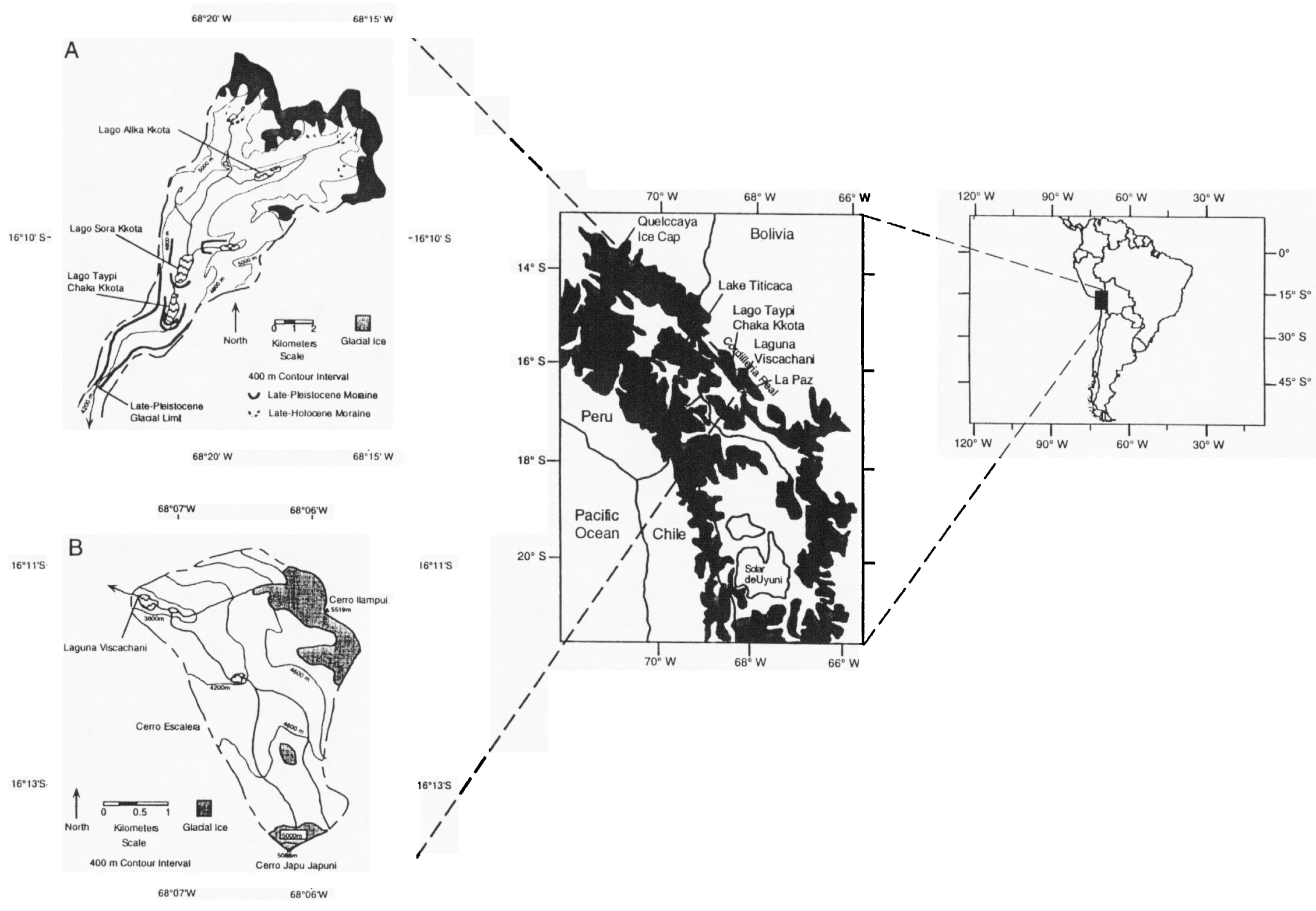

FIG. 1. Map showing the Cordillera Real and the Altiplano region in the northern Bolivian Andes (modified from Seltzer, 1994). Detailed maps of the Lago Taypi Chaka Kkota (A) and Laguna Viscachani (B) watersheds show the locations of the lakes and modern cirque glaciers. 
phase, resulting in the nearly complete melting of glaciers between 8900 and $2300{ }^{14} \mathrm{C}$ yr B.P. in watersheds with headwalls of $5500 \mathrm{~m}$ altitude and lower in the Cordillera Real, Bolivia. Terrestrial reconds of Holocene deglaciation based on radiocarbon dates of peat downvalley from terminal moraines indicate that the glaciers had receded to within 200 $\mathrm{m}$ of their modern extent by $9700-8600{ }^{14} \mathrm{C}$ yr B.P. (Seltzer, 1992; Seltzer et al., 1995). Late Holocene glacier advances appear to have obliterated evidence of any moraines that may have formed during the middle Holocene. Therefore, only by investigating lacustrine sediment records can we determine if glaciers melted completely during the early and middle Holocene. We also discuss a possible link between observed millennial-scale shifts in the regional precipitation-evaporation balance and seasonal shifts in insolation incident in the tropics of the Southern Hemisphere.

\section{CLIMATE SETTING OF STUDY AREA}

Pronounced seasonal contrasts in precipitation are characteristic of the Andean Altiplano (14-21 ${ }^{\circ} \mathrm{S}$ ). During the Austral summer, a heat-induced low-pressure cell forms over the center of South America that draws moisture from the South Atlantic. At the same time, convective activity over the Altiplano associated with the "Bolivian High" (Aceituno and Montecinos, 1993) produces precipitation in the Andes. As a result, most precipitation falls between December and March in this region. Periodic blocking of the easterly atmospheric circulation by the westerlies (Aceituno and Montecinos, 1993; Kessler, 1988) and perturbations caused by El Niño Southern Oscillation (ENSO) events (Thompson et al. 1984; Ribstein et al., 1995; Francou et al., 1995) can produce dry phases on the Altiplano during the normal wet season. We contend that the synoptic climatic conditions that lead to seasonal and intra-seasonal variations in effective moisture today on the Altiplano serve as reasonable analogs for changes that may have occurred over longer periods during the Holocene.

This study uses sediment records collected from both sides of the Cordillera Real, Bolivia, to investigate changes in effective moisture. The two study sites are separated by 25 km: Lago Taypi Chaka Kkota $\left(16^{\circ} 13^{\prime} \mathrm{S}, 68^{\circ} 21^{\prime} \mathrm{W}, 4300 \mathrm{~m}\right.$ altitude) is located in the Río Palcoco valley on the western side of the cordillera (Fig. IA). Laguna Viscachani $\left(16^{\circ} 12^{\prime} \mathrm{S}\right.$, $68^{\circ} 07^{\prime} \mathrm{W}, 3740 \mathrm{~m}$ ) is situated in the Río Zongo valley on the eastern side of the divide (Fig. 1B). Both watersheds contain small cirque glaciers, with headwalls at $5500 \mathrm{~m}$ altitude.

The eastern cordillera of the northern Bolivian Andes is a zone of steep climatic gradients resulting from a relief of $>600 \mathrm{~m}$ above the Amazon Basin. The result is a pronounced rain shadow, with precipitation decreasing east to west from $>1400 \mathrm{~mm} / \mathrm{yr}$ in the lowlands to $<700 \mathrm{~mm} / \mathrm{yr}$ in the Altiplano (Hoffman, 1975). Roche et al. (1992) estimated that the highest peaks of the Cordillera Real receive $>800 \mathrm{~mm} / \mathrm{yr}$ precipitation; $50 \mathrm{~km}$ to the west over the Altiplano this decreases to $<500 \mathrm{~mm} / \mathrm{yr}$. Ribstein et al. (1995) measured $\sim 900 \mathrm{~mm}$ of precipitation during the 1992-1993 hydrological year on Zongo Glacier, located on the continental divide $10 \mathrm{~km}$ from Laguna Viscachani and $20 \mathrm{~km}$ from Lago Taypi Chaka Kkota. Summer precipitation (December-March) accounts for 65 to $78 \%$ of the annual total, and winter precipitation accounts (June-September) for only 3 to $8 \%$ of the annual total (Roche et al., 1992).

\section{METHODS}

Cores were taken with a square-rod piston corer (Wright et al., 1984) and a piston corer designed to collect undisturbed sediment-water interface profiles (Fisher $e t$ al., 1992). Total carbon (TC) and total inorganic carbon (TIC) were measured with a UIC Coulometric System. Total organic carbon (TOC) was calculated by the difference of TC-TIC. Biogenic-silica was analyzed by a time-series dissolution experiment (DeMaster, 1979; DeMaster, 1981). Core lithology was determined from smear-slide mineralogy and detailed inspection of sediments noting Munsel color, texture, sedimentary structures, and biogenic features. Magnetic susceptibility was measured with a Bartington Susceptibility Bridge at low frequency. Values were corrected for mass differences with bulk density measurements.

Terrestrial macrofossils were not present in sufficient quantities for AMS ${ }^{14} \mathrm{C}$ measurements at most stratigraphic levels. Therefore, we used Isoetes macrofossils for AMS ${ }^{14} \mathrm{C}$ measurements from Lago Taypi Chaka Kkota and Myriophyllum macrofossils from Laguna Viscachani. The contemporary radiocarbon reservoir was assessed by measuring the ${ }^{14} \mathrm{C}$ activity of live samples of these submerged macrophytes from each lake. The results of radiocarbon measurements of living aquatic vegetation are 114 and $111 \%$ Modern for the years A.D. 1992 and 1994, respectively, indicating that the lake reservoir effects are minimal in these systems; however, it is possible that the reservoir age has changed with time.

The radiocarbon ages were measured at the Center for Accelerator Mass Spectrometry (CAMS), Lawrence Livermore National Laboratory. Radiocarbon ages are reported either as ${ }^{14} \mathrm{C}$ yr B.P. (uncalibrated) or cal ${ }^{14} \mathrm{C}$ yr B.P. if corrected and calibrated according to the methods outlined for CALIB 3.0 by Stuiver and Reimer (1993). Accumulation rates $\left(\mathrm{g} / \mathrm{cm}^{2} / 100 \mathrm{yr}\right)$ were calculated using calibrated dates as products of sediment accumulation rates $(\mathrm{cm} / \mathrm{yr})$ and bulk density $\left(\mathrm{g} / \mathrm{cm}^{3}\right)$ without considering errors associated with radiocarbon measurements or calibration.

\section{RESULTS}

\section{Lago Taypi Chaka Kkota}

AMS ${ }^{14} \mathrm{C}$ dates indicate that the transition from glacial silt to organic-rich lacustrine sediments occurred at 10,790 


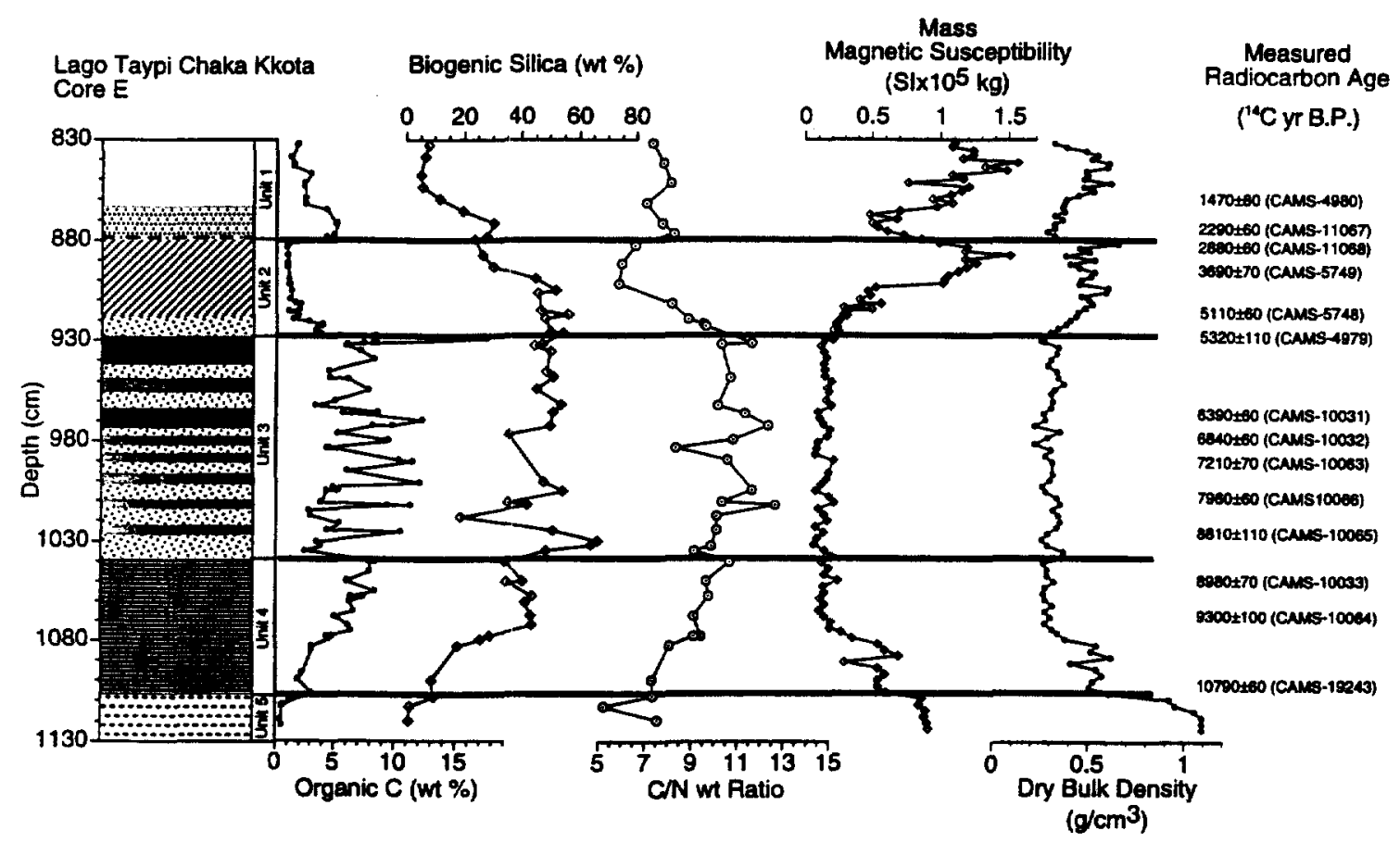

FIG. 2. Radiocarbon ages and sediment properties, including organic carbon, biogenic silica, $\mathrm{C} / \mathrm{N}$ ratio, mass magnetic susceptibility, and dry bulk density, from core E collected from Lago Taypi Chaka Kkota.

$\pm 60{ }^{14} \mathrm{C}$ yr B.P. (CAMS-19243) in the Lago Taypi Chaka Kkota lake basin $(4300 \mathrm{~m})$, which is located more than 10 $\mathrm{km}$ downvalley and $1200 \mathrm{~m}$ below the catchment headwall $(5500 \mathrm{~m})$ (Fig. 2. Table 1). Seltzer (1992) estimated that the time of maximum late Pleistocene glaciation in Bolivia (Choqueyapu II Glaciation) was about $14,000{ }^{14} \mathrm{C}$ yr B.P. based on glacial-geologic studies in the Bolivian-Peruvian Andes. Gouze et al. (1986) obtained a maximum limiting age for the Choqueyapu II glaciation of $16,600 \pm 130{ }^{14} \mathrm{C}$ yr B.P. on the western side of the Cordillera Real. In the Rio Palcoco valley, the terminal moraine assurned to have formed during the Choqueyapu II glaciation is $\sim 5 \mathrm{~km}$ downvalley from Lago Taypi Chaka Kkota. Seltzer (1991) described rapid deglaciation of the Río Palcoco valley on the basis of bulk radiocarbon dates obtained from the base of the organic-rich lacustrine deposits in Lago Taypi Chaka Kkota and Lago Allka Kkota, situated less than $3 \mathrm{~km}$ from the headwall. These dates are 10,460 \pm 140 (Beta-35071) and $9980 \pm 90{ }^{14} \mathrm{C}$ yr (Beta-35069), respectively. Furthermore, the glaciers receded to within their Neoglacial limit by $8640 \pm 80^{1+} \mathrm{C}$ yr (Beta-35052) as indicated by a date from the transition of glacial silt to fibrous peat in a bog $200 \mathrm{~m}$ from the present glacier front at $4670 \mathrm{~m}$ (Seltzer, 1991). Glacier advances during the late Holocene extended less than $200 \mathrm{~m}$ from the present glacier fronts in the Cordillera Real (Gouze et al.. 1986; Seltzer, 1990).

The sediments that accumulated in Lago Taypi Chaka
Kkota between $9300 \pm 100$ (CAMS-10064) and $8810 \pm 110$ ${ }^{14} \mathrm{C}$ yr (CAMS-10065) have higher concentrations of organic matter and biogenic silica, and a fourfold increase in accumulation rate compared to sedimentation between 10,790 . and $9300 \pm 100{ }^{14} \mathrm{C}$ yr B.P. (Figs. 2 and 3). Between 10,790. \pm 60 and $9300 \pm 100{ }^{14} \mathrm{C}$ yr B.P. the inorganic content of the sediments decreased from $>80$ to $<40 \%$, indicating that the glacial sediment source was greatly reduced or absent. Biogenic silica increased from $<20$ to $>60 \%$ just prior to $9300 \pm 100{ }^{14} \mathrm{C}$ yr. This shift signals a marked increase in lake productivity and corresponds with a continued increase in accumulation rate. Well-preserved Isoetes plant fragments occur above the $1080 \mathrm{~cm}$ level, suggesting a reduction in the concentration of glacial silt in the water column, allowing light transmission to the lake bottom. The higher lake productivity is consistent with increased nutrient input into the lake system during the initial stages of soil stabilization in a recently deglaciated watershed.

A marked shift in the sedimentation pattern occurred after $8810 \pm 110$ yr B.P., based on a change from mm-scale laminations to $\mathrm{cm}$-scale bands. The $\mathrm{cm}$-scale bands that formed between $8810 \pm 110$ and $5320 \pm 110{ }^{14} \mathrm{C}$ yr B.P. (CAMS-4979) alternate between dark-brown laminae containing aquatic macrophytes and megaspores and light-gray laminae with lower organic carbon content and lacking wellpreserved macrofossils. Two hypotheses are proposed to explain the $\mathrm{cm}$-scale bands. One is that variations in glacier 
TABLE 1

AMS Radiocarbon Dates from Lago Taypi Chaka Kkota and Laguna Viscachani

\begin{tabular}{|c|c|c|c|c|c|}
\hline Lake & Depth $(\mathrm{cm})$ & Material & $\begin{array}{c}\text { Measured }{ }^{14} \mathrm{C} \text { age } \\
\left({ }^{14} \mathrm{C} \text { yr B.P. }\right)\end{array}$ & $\begin{array}{c}\text { Median calibrated }{ }^{14} \mathrm{C} \text { age } \\
\text { (Cal }{ }^{14} \mathrm{C} \text { yr B.P.) }\end{array}$ & CAMS-\# \\
\hline Lago Taypi Chaka Kkota & 860.5 & aquatic macrofossil & $1470 \pm 80$ & 1310 & $4980^{\circ}$ \\
\hline Lago Taypi Chaka Kkota & 879.5 & aquatic macrofossil & $2290 \pm 60$ & 2230 & 11,067 \\
\hline Lago Taypi Chaka Kkota & 882.5 & aquatic macrofossil & $2880 \pm 60$ & 2940 & 11,068 \\
\hline Lago Taypi Chaka Kkota & 893.5 & aquatic macrofossil & $3690 \pm 70$ & 3950 & 5749 \\
\hline Lago Taypi Chaka Kkota & 919.5 & aquatic macrofossil & $5110 \pm 60$ & 5820 & 5748 \\
\hline Lago Taypi Chaka Kkota & 928.5 & aquatic macrofossil & $5320 \pm 110$ & 6030 & 4979 \\
\hline Lago Taypi Chaka Kkota & 971 & aquatic macrofossil & $6390 \pm 60$ & 7223 & 10,031 \\
\hline Lago Taypi Chaka Kkota & 981 & aquatic macrofossil & $6840 \pm 60$ & 7580 & 10,032 \\
\hline Lago Taypi Chaka Kkota & 988.5 & aquatic macrofossil & $7210 \pm 70$ & 7940 & 10,063 \\
\hline Lago Taypi Chaka Kkota & 1011.5 & aquatic macrofossil & $7960 \pm 60$ & 8680 & 10,066 \\
\hline Lago Taypi Chaka Kkota & 1028 & aquatic macrofossil & $8810 \pm 110$ & 9730 & 10,065 \\
\hline Lago Taypi Chaka Kkota & 1054 & aquatic macrofossil & $8980 \pm 70$ & 9950 & 10,033 \\
\hline Lago Taypi Chaka Kkota & 1069.5 & aquatic macrofossil & $9300 \pm 100$ & 10,260 & 10,064 \\
\hline Lago Taypi Chaka Kkota & 1104.5 & aquatic macrofossil & $10,790 \pm 60$ & 12,680 & 19,243 \\
\hline Laguna Viscachani & 523 & aquatic macrofossil & $1220 \pm 80$ & 1070 & 17,011 \\
\hline Laguna Viscachani & 527 & aquatic macrofossil & $1380 \pm 90$ & 1290 & 17,012 \\
\hline Laguna Viscachani & 580 & aquatic macrofossil & $2480 \pm 60$ & 2420 & $17,010^{\circ}$ \\
\hline Laguna Viscachani & 574 & aquatic macrofossil & $2510 \pm 80$ & 2650 & 17.013 \\
\hline Laguna Viscachani & 619.5 & aquatic macrofossil & $5450 \pm 90$ & 6250 & 16,063 \\
\hline Laguna Viscachani & 638 & aquatic macrofossil & $6080 \pm 60$ & 6880 & 17,014 \\
\hline Laguna Viscachani & 697 & aquatic macrofossil & $8550 \pm 70$ & 9480 & 17,015 \\
\hline Laguna Viscachani & 725.5 & aquatic macrofossil & $9590 \pm 70$ & 10,760 & 16,064 \\
\hline Laguna Viscachani & 737 & aquatic macrofossil & $9790 \pm 70$ & 10,970 & 17,016 \\
\hline
\end{tabular}

"Not used in sedimentation rate calculations.

activity drove century-scale changes in sediment input to the lake basin; the other is that variable lake level occurred during the middle Holocene, caused by the disappearance of glaciers from the watershed and the loss of glacial meltwater as a buffer during the dry season.

In the first hypothesis, increased glacier activity may explain the formation of the light-gray cm-scale bands. Although a small increase in the mineral content of the light bands is noted, the inorganic accumulation rate is decreased in these intervals. This is not consistent with the inference of increased glacier activity. Furthermore, the biogenic-silica content of the light cm-scale bands remains $>40 \%$, in contrast to values of $<5 \%$ at present and $<2 \%$ during the early Holocene. Therefore, this hypothesis is considered unlikely.

In the second hypothesis, modern analogs are offered to aid the interpretation of the past system. Isoetes is found only in very shallow water ( $<1 \mathrm{~m}$ deep) in the contemporary system. Assuming this was also true in the past, the dark $\mathrm{cm}$-scale laminae that contain well-preserved Isoetes plant matter could only be formed during century-scale periods when the lake level was seasonally below its overflowing stage. This implies that glaciers were greatly reduced or absent from the watershed after $8810 \pm 110{ }^{14} \mathrm{C}$ yr B.P. and is consistent with sedimentological evidence provided above. Low lake levels are unlikely in the modern system because glacial meltwater maintains the water level at its overflowing stage even during the dry season. A modern example of a similar lake system without glaciers in it's watershed is Laguna Kollpa Kkota $\left(17^{\circ} 26^{\prime} S, 67^{\circ} 88^{\prime} \mathrm{W}, 4400\right.$ $m$ ). In this system, lake level is seasonally lower and the lake often is desiccated during the dry season because the catchment lacks glaciers to buffer water level (Seltzer, 1994).

A marked decrease in the organic carbon content occurs at $5320 \pm 110^{14} \mathrm{C}$ yr B.P. This suggests lower lake productivity or increased decomposition of organic matter during the period between $5320 \pm 110$ and $2880 \pm 60$ yr B.P. (CAMS-11068). Furthermore, increases in the inorganic matter content, mass magnetic susceptibility, and bulk density occur with little change in the rate of inorganic sedimentation. Again, two hypotheses could explain this interval. Either the lake system returned to overflowing conditions after $5320 \pm 110{ }^{14} \mathrm{C}$ yr B.P. or the lake was seasonally lower and occasionally desiccated after this time.

If the first hypothesis is correct, decreased lake productivity signals the return of year-round overflowing conditions driven by the return of cirque glaciers to the Lago Taypi Chaka Kkota watershed. However, this is inconsistent with the erosion history of the catchment, as recorded in the lake sediments. Increased glacier activity would have resulted in greater input of fine-grained glacial sediment, producing higher accumulation rates and lower lake productivity. Although trends in sediment analyses are consistent with lower 


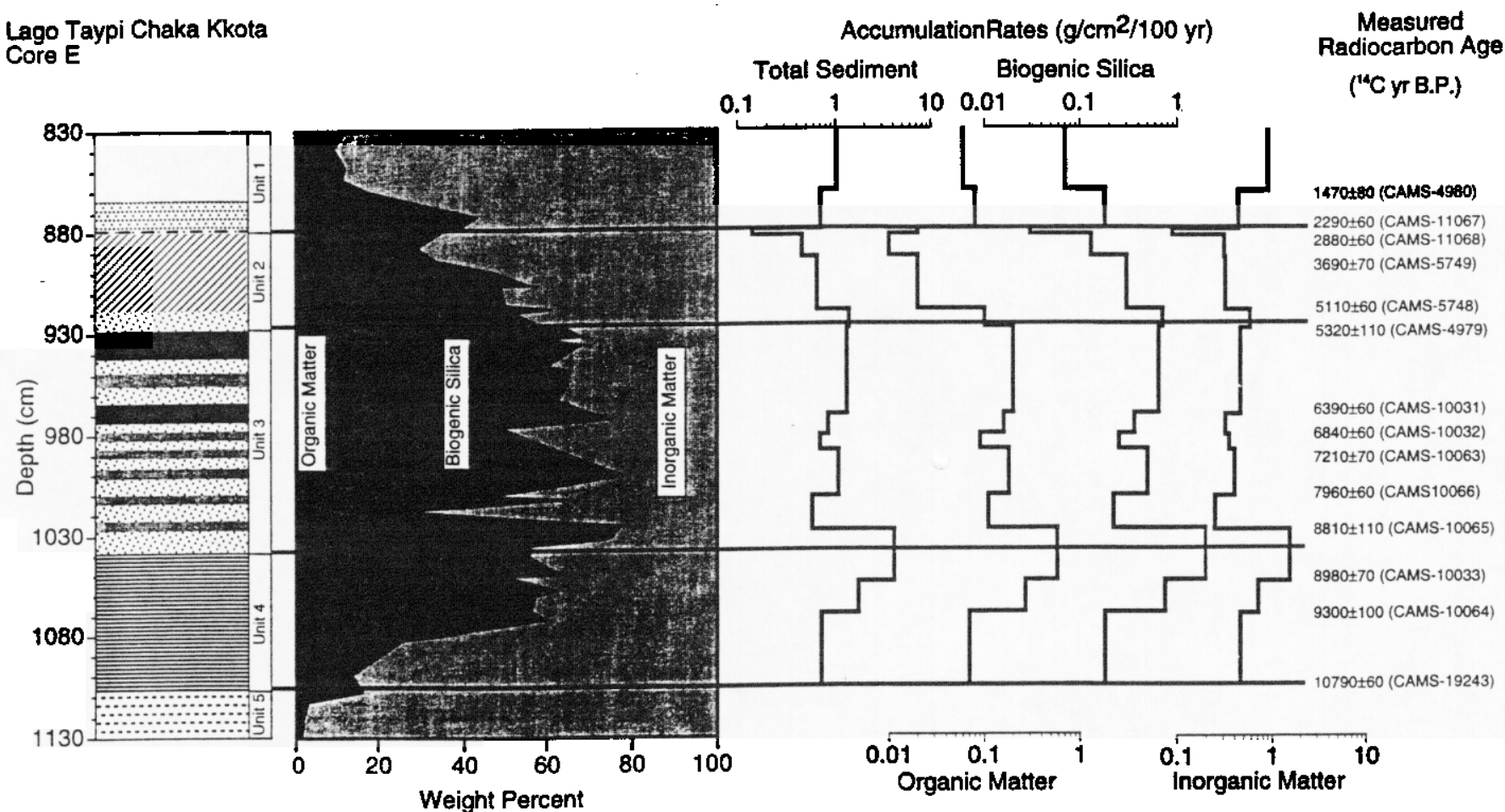

FIG. 3. Comparison of organic matter, biogenic-silica, and inorganic matter content and their respective accumulation rates plotted on a log scale from core $\mathrm{E}$ in Lago Taypi Chaka Kkota.

productivity, the total accumulation rate decreased in the interval from $5320 \pm 110$ to $2290 \pm 60{ }^{14} \mathrm{C}$ yr B.P. (CAMS11067). The average inorganic accumulation rate for this period $\left(0.4 \mathrm{~g} / \mathrm{cm}^{2} / 100 \mathrm{yr}\right)$ dropped to less than half the rate calculated for the modern system $\left(0.9 \mathrm{~g} / \mathrm{cm}^{2} / 100 \mathrm{yr}\right)$. This suggests that if glaciers were present, they were less extensive than now.

If the second hypothesis is correct, the lake would have been seasonally lower or desiccated during the dry season for the period from $5320 \pm 110$ to $2290 \pm 60{ }^{14} \mathrm{C} \mathrm{yr}$ B.P. Accumulation rates reach the lowest Holocene values during this phase, suggesting that sediments could have been partially lost by deflation when the lake was desiccated. Seasonal exposure of organic sediments may have resulted in higher rates of organic matter oxidation (Killops and Killops. 1993) and increased bulk density. Progressive decreases in organic carbon and biogenic-silica combined with increases in bulk density, inorganic matter content, and mass magnetic susceptibility are consistent with desiccation surfaces. The decreases in accumulation rates described above and the apparent unconformity from $2880 \pm 60$ to $2290 \pm 60{ }^{14} \mathrm{C}$ yr B.P. $(880 \mathrm{~cm})$ suggest that the lake was seasonally dry or desiccated for an extended period prior to $2290 \pm 60{ }^{14} \mathrm{C}$ yr B.P. Peaks in mass magnetic susceptibility and ARM magnetization occur at the $887 \mathrm{~cm}$ level. Water levels in Lake Titicaca dropped
10 to $12 \mathrm{~m}$ between 2450 and $2250{ }^{14} \mathrm{C}$ yr B.P. before rising abruptly after $2250{ }^{14} \mathrm{C}$ yr B.P., supporting the hypothesis of a dry phase at this time (Abbott, 1995).

Above the $2290 \pm 60{ }^{14} \mathrm{C}$ yr B.P. level in the sediment core, abrupt increases in organic carbon and biogenic-silica, combined with decreases in mass magnetic susceptibility and bulk density, indicate a return to more humid environmental conditions and higher lake productivity. These conditions were temporary, as organic carbon and biogenic-silica content decreased rapidly to near late Pleistocene values by 1470 $\pm 80{ }^{14} \mathrm{C}$ yr B.P. (CAMS-4980). After this time, inorganic content, mass magnetic susceptibility, and bulk density increased rapidly. Organic carbon accumulation rates fell abruptly to the lowest Holocene values $\left(<0.1 \mathrm{~g} / \mathrm{cm}^{2} / 100 \mathrm{yr}\right)$ and the inorganic accumulation rates increased to the highest values since the early Holocene $\left(>0.9 \mathrm{~g} / \mathrm{cm}^{2} / 100 \mathrm{yr}\right)$, when the glaciers were in the final stages of recession.

\section{Laguna Viscachani}

The transition from glacial silts to organic-rich lacustrine sediments occurred at $9790 \pm 70 \mathrm{yr}$ B.P. (CAMS-17016) in Laguna Viscachani $(3740 \mathrm{~m})$. This contact is $1000{ }^{14} \mathrm{C} \mathrm{yr}$ younger than the $10,790 \pm 60{ }^{14} \mathrm{C}$ yr B.P. age obtained from Lago Taypi Chaka Kkota $(4300 \mathrm{~m})$ on the western side of the range. The latest Pleistocene ice limit in the Lago Taypi 


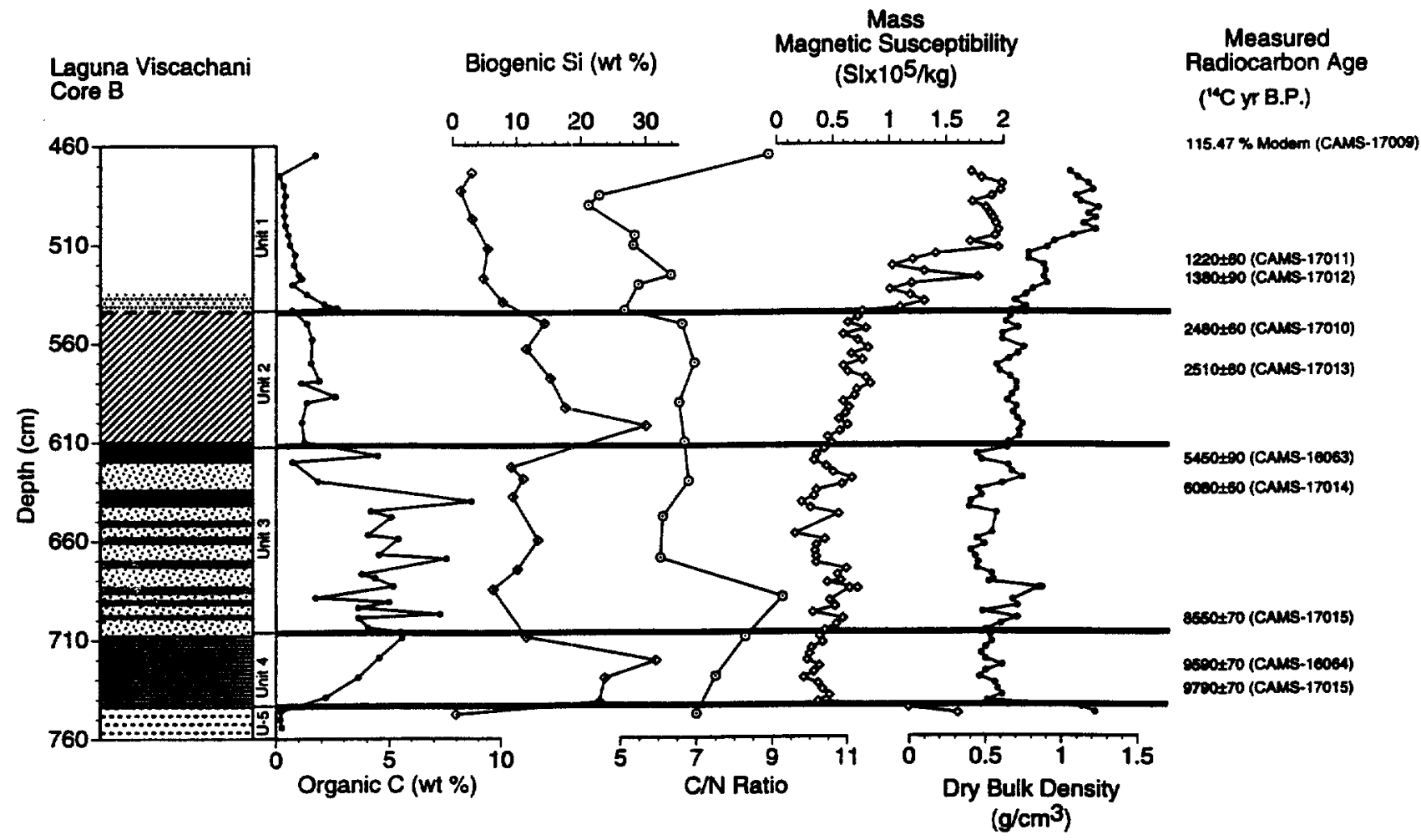

FIG. 4. Radiocarbon ages and sediment properties. including organic carbon, biogenic silica, C/N ratio, mass magnetic susceptibility, and dry bulk density, from core B collected from Laguna Viscachani.

Chaka Kkota watershed is at $\sim 4200 \mathrm{~m}$ altitude, indicating that glaciers on the eastern side of the mountains advanced at least $460 \mathrm{~m}$ lower than those on the west. This supports modern observations of a pronounced rain shadow across the Cordillera Real (Seltzer, 1990). Therefore, the Laguna Viscachani watershed should receive higher average annual precipitation and be more prone to the regeneration of cirque glaciers after the middle Holocene dry phase than the Lago Taypi Chaka Kkota catchment. Furthermore, the higher precipitation on the eastern side of the Cordillera Real renders Laguna Viscachani less susceptible to periods of prolonged dry-season desiccation.

After $9790 \pm 70{ }^{1+} \mathrm{C}$ yr B.P., abrupt increases in organic matter and biogenic-silica content signal higher lake productivity. Figures 4 and 5 show that organic matter $(>0.2 \mathrm{~g} /$ $\left.\mathrm{cm}^{2} / 100 \mathrm{yr}\right)$ and biogenic-silica ( $\left.>0.7 \mathrm{~g} / \mathrm{cm}^{2} / 100 \mathrm{yr}\right)$ accumulation rates were at their highest Holocene levels. Organic matter sedimentation decreased from $9790 \pm 70$ to $5450 \pm$ $90{ }^{1+} \mathrm{C}$ yr B.P. (CAMS-16063), when it reached it's lowest Holocene level of $0.03 \mathrm{~g} / \mathrm{cm}^{2} / 100 \mathrm{yr}$. The biogenic-silica accumulation rate decreased before stabilizing after $8550 \pm$ $70{ }^{14} \mathrm{C}$ yr B.P. (CAMS-17015). The inorganic accumulation rate was stable after $9590 \pm 70{ }^{14} \mathrm{C}$ yr B.P. (CAMS-16064) until $5450 \pm 90{ }^{14} \mathrm{C}$ yr B.P. The subfacies formed during the middle Holocene vary from organic-rich laminae containing well-preserved macrophytes to lower organic sediments without macrofossils. These deposits are consistent with a lake system that shifted between overflowing conditions and seasonally lower water levels.

Decreased accumulation rates between $5450 \pm 90$ and $2510 \pm 80{ }^{14} \mathrm{C}$ yr B.P. (CAMS-17013) were synchronous with a similar trend in Lago Taypi Chaka Kkota. This supports the hypothesis that water levels were seasonally lower. Furthermore, the inorganic accumulation rate is the lowest of any period during the Holocene $\left(0.5 \mathrm{~g} / \mathrm{cm}^{2} / 100 \mathrm{yr}\right)$, suggesting that cirque glaciers were not present in these watersheds. An initial increase in the biogenic-silica content followed by a steady decline from $5450 \pm 90$ to $2510 \pm 80$ ${ }^{14} \mathrm{C}$ yr B.P. is the same trend observed in the Lago Taypi Chaka Kkota core during this period.

After $2510 \pm 80{ }^{14} \mathrm{C}$ yr B.P., accumulation rates of organic matter, biogenic-silica, and inorganic matter increased. The largest increase was in the inorganic matter accumulation rate from $\sim 1.0$ to $2.2 \mathrm{~g} / \mathrm{cm}^{2} / 100 \mathrm{yr}$. An abrupt increase in the mass magnetic susceptibility after $2480 \pm 60{ }^{14} \mathrm{C}$ yr B.P. (CAMS-17010) and inorganic matter content are consistent with the return of cirque glaciers in the Laguna Viscachani catchment. After $1220 \pm 80{ }^{14} \mathrm{C}$ yr B.P. (CAMS-17011), the accumulation rate of inorganic matter doubled. This is coincident with the stabilization of increased values of mass 


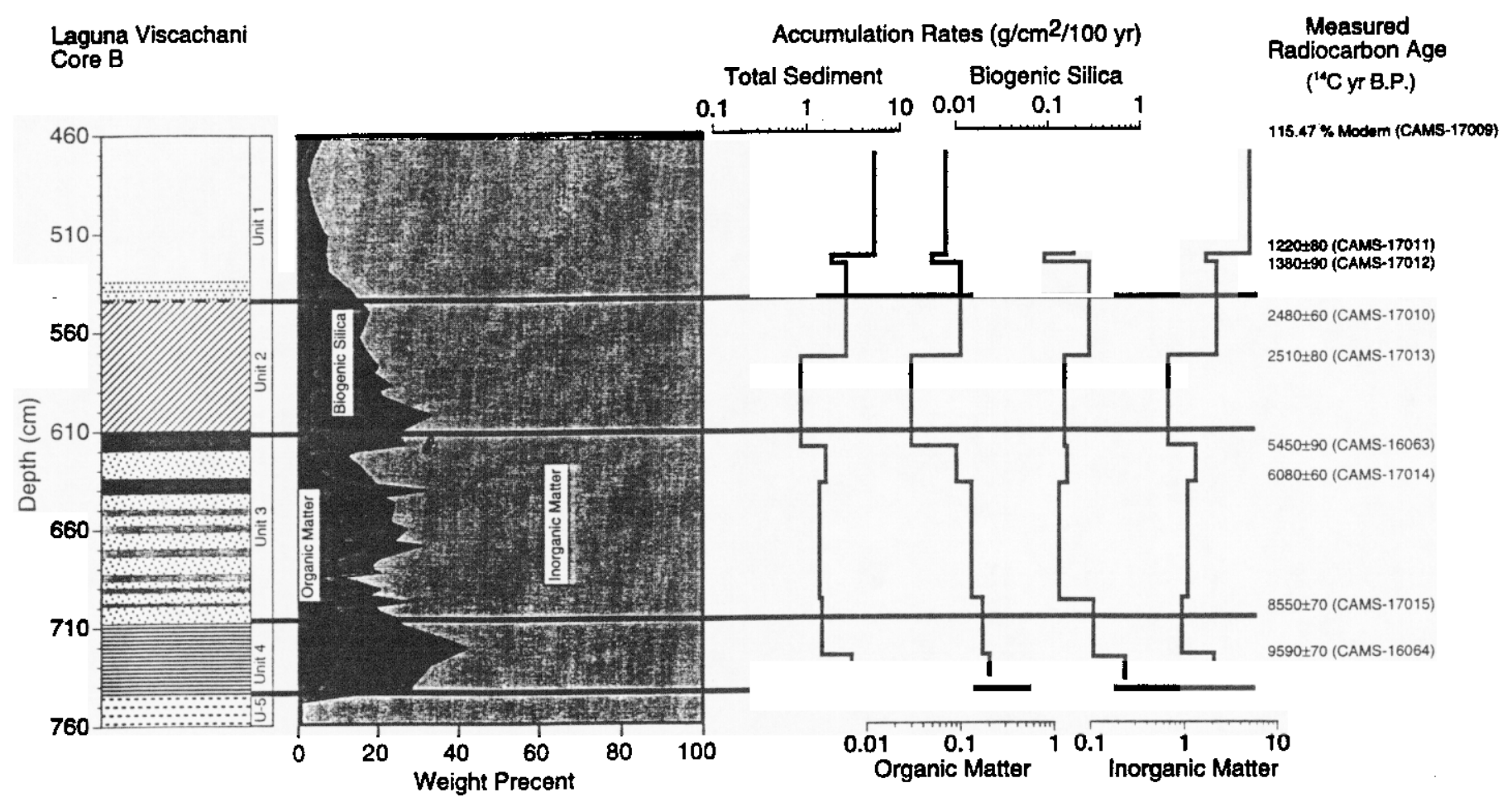

FIG. 5. Comparison of organic matter, biogenic-silica, and inorganic matter content and their respective accumulation rates plotted on a log scale from core B in Laguna Viscachani.

magnetic susceptibility and bulk density, suggesting Neoglaciation. Furthermore, organic matter and biogenic-silica content returned to pre-Holocene values.

\section{CLIMATIC CONTROLS ON REGIONAL GLACIATION}

Little information exists on the mid-Holocene activity of glaciers in the tropical Andes. In northern Bolivia we can say with certainty that deglaciation at the end of the Pleistocene proceeded rapidly, so that by $\sim 10,000{ }^{14} \mathrm{C}$ yr B.P. many glaciers were near or within their modern limits. In the late Holocene Neoglaciation is evidenced by extensive, sparsely vegetated moraines only within $200 \mathrm{~m}$ of modern glaciers. However, there is little geomorphic record of mid-Holocene glacier activity in this area.

We suggest that glaciers are critical for maintaining the perennial lakes in the Cordillera Real. During the extensive dry period that occurs every year in the austral winter, meltwater generation from glaciers in these watersheds appears to maintain the overflowing condition of the lakes. This is supported by the observation that ephemeral lakes in the cordillera occur in basins that are not linked to modem glaciers. Thus, factors that influence glacier mass balance may also indirectly influence the hydrologic mass balance of the lakes.

Francou et al. (1995) assessed the mass balance of Zongo
Glacier $\left(16^{\circ} 17^{\prime} \mathrm{S}, 68^{\circ} 09^{\prime} \mathrm{W}, 6000-4890 \mathrm{~m}\right)$ and measured water discharge, temperature, and precipitation from September 1991 through August 1993 to determine the response . of modern tropical glaciers to climatic variability. Zongo Glacier is on the eastern side of the Huayna Potosi massif $<10 \mathrm{~km}$ from Laguna Viscachani. The study period spanned a strong ENSO event that occurred during the summer of 1991 - 1992. Francou et al. (1995) compared the "normal" 1992-1993 hydrological year with the 1991-1992 ENSO event and concluded that (1) there was a marked negative water balance during the ENSO event year, with water loss amounting to twice the precipitation gain, (2) the equilibrium-line altitude of the glacier rose $200 \mathrm{~m}$, (3) the glacier accumulation-area ratio (AAR) decreased from 86 to $58 \%$, and (4) a very low accumulation rate occurred at high elevations. These effects are directly related to increased radiation receipt at the glacier surface, which causes warmer summer temperatures and results in a higher rate of ablation. Furthermore, the summer wet season lasted only 2 months during the 1991-1992 ENSO event instead of the 4 months of a "normal" hydrological year.

Francou et al. (1995) concluded that factors controlling the mass balance of glaciers in the tropics include the duration of the wet season, and the temperature during the periods that precede and follow the rainy season. Temperature and precipitation during the months of October-December and March- 
May appear to be critical for determining the mass balance of tropical glaciers. The association of ENSO events with low accumulation or negative mass balance reported by Francou et $a l$. is paralleled by ice-core evidence of decreased precipitation on the Quelccaya ice cap (Thompson et al., 1985).

Ribstein et al. (1995) observed that during the 19911992 ENSO event, Zongo Glacier produced increased runoff despite lower precipitation values compared with the 19921993 "normal" hydrological year. The decrease in precipitation corresponded to decreased cloud cover, which allowed more solar radiation to reach the glacier surface. Thus, extended periods of low precipitation would first lead to increased meltwater production by the glaciers followed by desiccation of these valleys after the glaciers had completely ablated.

Wetter conditions on the northern Altiplano are associated with the Bolivian High, which develops as a result of convective precipitation over this region in the austral summer (J. Lenters and $\mathrm{K}$. Cook, unpub. data). We assume here that any decrease in summer insolation would be related to a decrease in precipitation on the Altiplano, thereby having the effect of decreasing cloudiness and increasing the receipt of solar radiation at the glacier surface. Given the conceptual model above, the glaciers would ablate and eventually disappear if these phases lasted long enough. Also, an increase in insolation in the austral winter would lead to increased glacier ablation during that season.

GCM simulations by Kutzbach and Guetter (1986) showed that at 9000 yr B.P. $\left(\sim 8450{ }^{14} \mathrm{C}\right.$ yr B.P.) when perihelion occurred in July the seasonality of solar radiation was decreased in the Southern Hemisphere. Climate model simulations, predicted that incident solar radiation was decreased in January by $28 \mathrm{~W} / \mathrm{m}^{2}(6 \%)$ and increased in July by $11 \mathrm{~W} / \mathrm{m}^{2}(5 \%)$ relative to the A.D. 1950 value (Fig. $6 \mathrm{~A}$ ). These changes caused (1) decreased seasonality, resulting in cooler summers and warmer winters, (2) decreased sea-level pressure over the ocean and increased sea-level pressure over land, resulting in a lower pressure gradient and decreased transport of water vapor over the continent, and (3) a decrease in the net precipitation-evaporation balance, with the decreased precipitation being more significant than the decreased evaporation. The summer and winter average insolation values returned to near-modern levels and the rate of change slowed about 3000 yr B.P. $\left(\sim 2900{ }^{14} \mathrm{C}\right.$ yr B.P.) which generally corresponds with wetter conditions on the Altiplano (Fig. 6A). Figure 6B illustrates a plot of monthly insolation at $20^{\circ} \mathrm{S}$ for the Austral summer and transitional months for the past 20,000 yr. For the months of DecemberFebruary which are the peak of the wet season, insolation values were at their lowest between 12,000 and 8000 yr B.P. $\left(\sim 10.000-7600{ }^{14} \mathrm{C}\right.$ yr B.P.) (Edwards et al., 1993), which corresponds with deglaciation and the beginning of the midHolocene dry phase observed at the sites in this study. Insol-
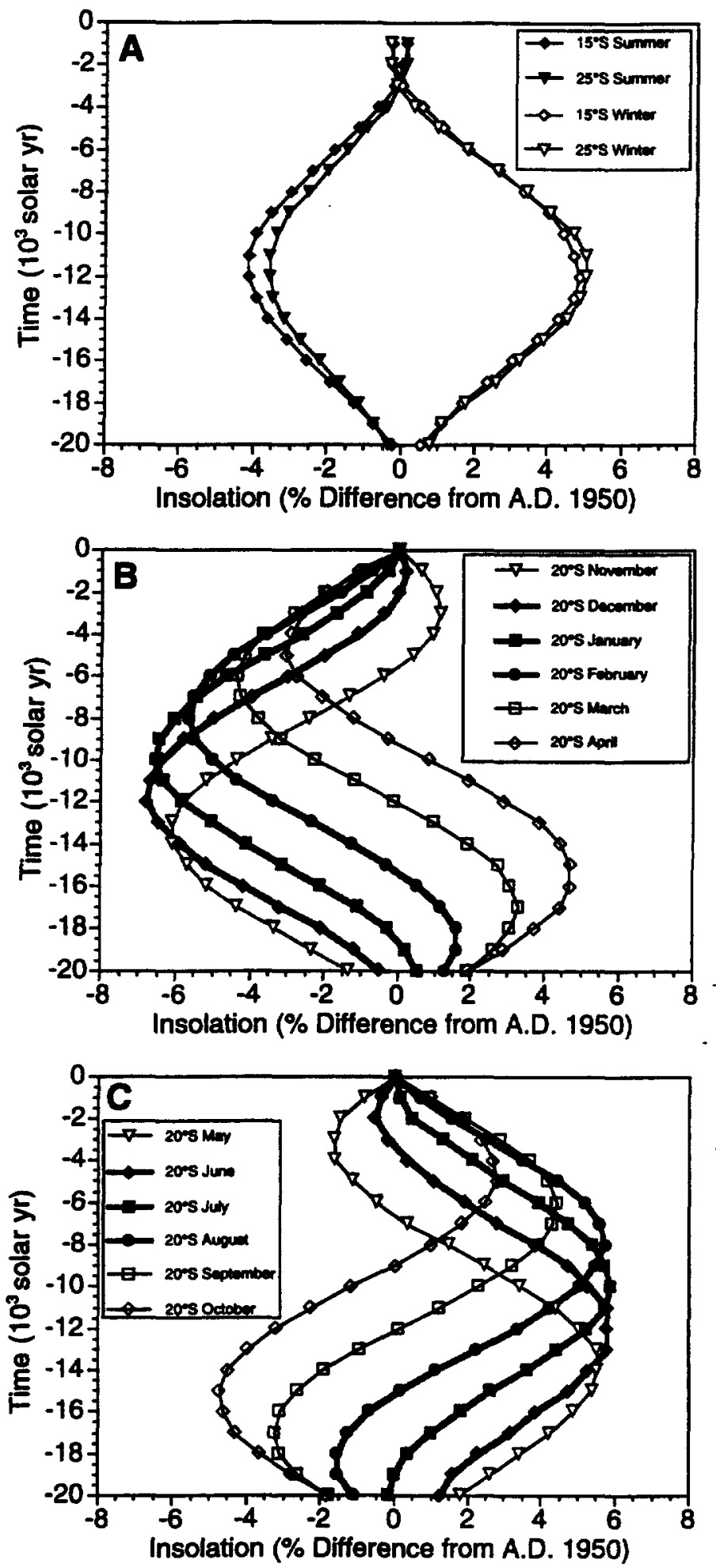

FIG. 6. Insolation changes for the past 20,000 yr B.P. as calculated from values given by Berger (1978a), Berger (1978b), and Berger and Loutre (1991). (A) Summer and winter insolation values for $15^{\circ} \mathrm{S}$ and $25^{\circ}$ showing seasonal insolation values reach present levels after 4000 yr B.P. (3700 ${ }^{1+} \mathrm{C}$ yr B.P.). Summer and winter values are defined as the 90 day period centered on the solstice. (B) Monthly insolation for the summer wet season and (C) for the winter dry season. 
ation values for the months of June-August reached their highest between 13,000 and 7000 yr B.P. $\left(11,000-6600{ }^{14} \mathrm{C}\right.$ yr B.P.), likely resulting in increased ablation during the winter months (Fig. 6C). Thus, seasonality in the Southern Hemisphere was decreased over the past $20,000 \mathrm{yr}$, peaking at the Pleistocene/Holocene transition. Given the scenario above, a decrease in summer insolation may have resulted in lower summer precipitation; an increase in winter insolation may have resulted in enhanced ablation of the glaciers during the winter months. The combination of decreased summer precipitation and increased melting in the winter would contribute to the disappearance of cirque glaciers from watersheds with headwalls lower than $5500 \mathrm{~m}$. Both factors would contribute to the prolonged dry phase in the middle Holocene documented in this study.

\section{CONCLUSIONS}

The sediment records from Lago Taypi Chaka Kkota and Laguna Viscachani contain striking similarities in the pattern and timing of geochemical, biological, and sedimentological changes, supporting the hypothesis that these systems are recording a regional climatic signal. Twenty-three AMS ${ }^{14} \mathrm{C}$ dates constrain the timing of the climatic shifts and yield sufficient time resolution to determine the Holocene erosion and deposition history of these catchments. Sediment core analyses showing abrupt shifts from nearly pure silt to increasingly organic-rich silt, suggest that glaciers receded above $4300 \mathrm{~m}$ altitude on the western side of the Cordillera Real by $10,700{ }^{14} \mathrm{C}$ yr B.P. and above $3740 \mathrm{~m}$ on the eastern side of the range by $9700{ }^{14} \mathrm{C}$ yr B.P. Increased accumulation rates of organic matter and biogenic silica, coupled with an abrupt decrease in the inorganic content of the sediments in both watersheds. suggests that the cirque glaciers disappeared between 9700 and $8900{ }^{14} \mathrm{C}$ yr B.P. High accumulation rates of organic carbon and biogenic silica from 9700 to $5400{ }^{14} \mathrm{C}$ yr indicate more favorable environmental conditions and higher lake productivity than today. $\mathrm{Cm}$-scale bands of sediments deposited during this period bear shallow-water macrophytes indicating water levels of $<1 \mathrm{~m}$ and alternate with laminae containing lower organic content and no macrofossils $>0.5 \mu \mathrm{m}$ in size. This suggests that there were century-scale periods of seasonally lower water levels. After $5400{ }^{14} \mathrm{C}$ yr B.P., macrophytes are absent from the sediments, but biogenic silica accumulation rates increase until the interval between 2900 and $2500{ }^{14} \mathrm{C}$ yr B.P. The Lago Taypi Chaka Kkota core shows an abrupt increase in inorganic content, bulk density, and mass magnetic susceptibility after $4000{ }^{1+} \mathrm{C}$ yr B.P., which is most likely the result of prolonged droughts leading to low-water stands during this interval. No such changes are observed in the Laguna Viscachani core during this time, but accumulation rates in both lakes reached their lowest level between 5400 and 2300
${ }^{14} \mathrm{C}$ yr B.P. A desiccated surface forming an uncontormity in the Lago Taypi Chaka Kkota core has an age of $2300{ }^{14} \mathrm{C}$ yr B.P., indicating that higher water levels were reached after this time. After $2300{ }^{14} \mathrm{C}$ yr B.P. sediment characteristics became increasingly similar to those of latest Pleistocene glacial sediments, indicating the return of cirque glaciers to watersheds with headwalls at $5500 \mathrm{~m}$ and intense Neoglacial activity after $1400{ }^{14} \mathrm{C}$ yr B.P.

\section{ACKNOWLEDGMENTS}

We thank Herbert Wright, Alexander Wolfe, and Ramon Aravena for providing critical comments on an earlier version of the manuscript. The Familia Ando of La Paz, The Servicio Geologico de Bolivia, and ORSTOMBolivia all provided valuable logistical assistance. We also thank Chalmers Clapperton and Eric Leonard for their reviews of this manuscript. The work was supported by a graduate fellowship and grants of the NSF-RTG at the University of Minnesota and the Limnological Research Center and field grants from Geological Society of America, Sigma Xi, and the Department of Geology and Geophysics, University of Minnesota.

\section{REFERENCES}

Abbott, M. B. (1995). Holocene climatic variability for lake sites in the Bolivian Andes and interior Alaska based on sedimentology and radiocarbon dating by accelerator mass spectrometry. Unpublished Ph.D. dissertation, University of Minnesota.

Abbott, M. B., Binford, M. W., Brenner, M., and Kelts, K. R. (in press). A $3500^{14} \mathrm{C}$ yr high-resolution record of lake level changes in Lake Titicaca, South America. Quatemary Research.

Aceituno. P., and Montecinos, A. (1993). Circulation anomalies associated with dry and wet periods in the South American Altiplano. In "Fourth International Conference on Southern Hemisphere Meteorology and Oceanography, American Meteorological Society," pp. 330-331.

Berger, A. (1978a). Long-term variations of daily insolation and Quatemary climatic changes. Joumal of Atmospheric Science 35, 2362-2367.

Berger, A. (1978b). A simple algorithm to compute long term variationsof daily or monthly insolation. Contribution No. 18, Université Catholique de Louvian, Institut d'Astronomie et de Geophysique, G. Lemaitre. Louvian-la-Neuve, B-1348 Belgique.

Berger. A., and Loutre, M. F. (1991). Insolation values for the climate of the last 10 million years. Quaternary Science Reviews 10, 297-317.

Binford, M. W., Kolata, A. L., Brenner, M., Janusek, J., Abbott. M. B., and Curtis, J. H. (in press). Climate variation and the rise and fall of an Andean civilization. Quatemary Research.

DeMaster, D. J. (1979). The marine budgets of silica and ${ }^{32} \mathrm{Si}$. Unpublished Ph.D. dissertation, Yale University, New Haven.

DeMaster. D. J. (1981). The supply and accumulation of silica in the marine environment. Geochemica et Cosmochimica Acta 45, 1715- 1732.

Edwards, R. L., Beck, W. J., Bur, G. S., Donahue, D. J., Chappell. J. M. A., Bloom. A. L., Druffel, E. R. M., and Taylor, F. W. (1993). A large drop in atmospheric ${ }^{14} \mathrm{C} /{ }^{12} \mathrm{C}$ and reduced melting in the Younger Dryas, documented with ${ }^{230} \mathrm{Th}$ ages of corals. Science 260, 962-968.

Fisher, M. M., Brenner, M., and Reddy, K. R. (1992). A simple, inexpensive piston corer for collecting undisturbed sediment/water interface profiles. Journal of Paleolimnology 7, 157-161.

Francou, B., Ribstein, P., Saravia, R., and Tiriau, E.. (1995). Monthly balance and water discharge of an inter-tropical glacier: Zongo Glacier, Cordillera Real, Bolivia 16; S. Joumal of Glaciology 41, 61-67. 
Gouze, P., Argollo. J.. Saliege. J.-F., and Servant, M. (1986). Interprétation paléoclimatique des oscillations des glaciers au cours des 20 demiers millénaires dans les régions tropicales: exemple des Andes Boliviennes. Comptes Rendus de L'Académie des Sciences Paris, Série II 303, 219223.

Hoffman, J. A. J. ( 1975). “Climatic Atlas of South America." World Meteorological Organization. Ginebra. Hungary.

Kessler, A. (1988). "Die Schwankungen des Wasserhaushaltes de südamerikanischen Altiplano und das Weltklima." v. Jahrbuch der Geographischen Gesellschaft zu Hannover, 139-159.

Killops. S. D., and Killops, V. J. (1993). "An Introduction to Organic Geochemistry." Longman Scientific \& Technical, New York.

Kutzabach, J. E., and Guetter, P. J. ( 1986). The influence of changing orbital parameters and surface boundary conditions on climate simulations for the past 18,000 years. Journal of the Atmospheric Sciences 43, 17261759.

Mourguiart, P. (1990). Une approche nouvelle du problème posé par les reconstrutions des paléoniveaux lacustres: utilisation d'une fonction de transfert basée sur les faunes d'ostracodes. Géodynamique 5, 151-166.

Ribstein, P., Tiriau. E., Francou, B.. and Saravia, R. (1995). Tropical climate and glacier hydrology: a case study in Bolivia. Journal of Hydrology 165, 221-234.

Roche, M. A., Bourges. J. C., and Mattos, R. (1992). Climatology and hydrology of the Lake Titicaca basin. In "Lake Titicaca: a synthesis of limnological knowledge“ (C. Dejoux and A. Iltis, Eds.), pp. 63-83. Kluwer, Boston.

Seltzer. G. O. (1990). Recent glacial history and paleoclimate of the Peruvian-Bolivian Andes. Quareman Science Reviews 9, 137--152.

Seltzer. G. O. (1991). Glacial history and climate change in the PenvianBolivian Andes. Unpublished Ph.D. dissertation, University of Minnesota.

This work was performed in part under the auspices of the U.S. Department of Energy at Lawerence Livermore National Laboratory under contract W-7405-ENG-48.
Seltzer, G. O. (1992). Late Quatemary glaciation of the Cordillera Real, Bolivia. Joumal of Quatemary Science 7, 87-98.

Seltzer, G. O. (1994). A lacustrine record of late Pleistocene climatic change in the subtropical Andes. Boreas 23, 105-111.

Seltzer, G. O., Rodbell, D. T.. and Abbott. M. B. (1995). Andean Glacial Lakes and Climate Variability Since the Last Glacial Maximum. Bulletin de l'Institut Francais d'Études Andines, 24, 539-550.

Servant. M., and Fontes, J.-C. (1978). Les Lacs quaternaires des hauts plateaux des Andes boliviennes: premieres interpretations paléoclimatiques. Cahiers de l'ORSTOM, Série Géologique 10, 9-23.

Stuiver, M., and Reimer, P. J. (1993). Extended ${ }^{1+} \mathrm{C}$ data base and revised CALIB $3.0{ }^{14} \mathrm{C}$ age calibration program. Radiocarbon 35, 215-230.

Thompson, L. G., Mosley-Thompson, E., Bolzan, J. F., and Koci. B. R. (1985). A 1500-yr record of tropical precipitation in ice cores from the Quelccaya Ice Cap, Peru. Science 229, 971-973.

Thompson, L. G., Mosley-Thompson, E., and Morales. B. (1984). El Niño Southem Oscillation events recorded in the stratigraphy of the tropical Quelccaya ice cap, Peru. Science 226, 50-53.

Wirmann, D., and Fernando De Oliveira Almeida, L. (1987). Low Holocene level ( 7700 to 3650 years ago) of Lake Titicaca (Bolivia). Palaeogeography, Palaeoclimatology, Palaeoecology 59, 315-323.

Wirmann, D., and Mourguiart, P. (1995). Late Quaternary spatio-temporal limnological variations in the Altiplano of Bolivia and Peru. Quateman Research 43, 344-354.

Wirmann. D., Mourguiart, P., and Fernando De Oliveira Almeida, L. (1990). Holocene sedimentology and ostracods distribution in Lake Titicaca-paleohydrological interpretations. In "Quaternary of South America and Antarctic Peninsula. Vol. 6" (J. Rabassa. Ed), pp. 89-129. A. A Balkema, Rotterdam.

Wright. H. E.. Mann, D. H., and Glaser. P. H. (1984). Piston corers for peat and lake sediments. Ecology 65, 657-659. 


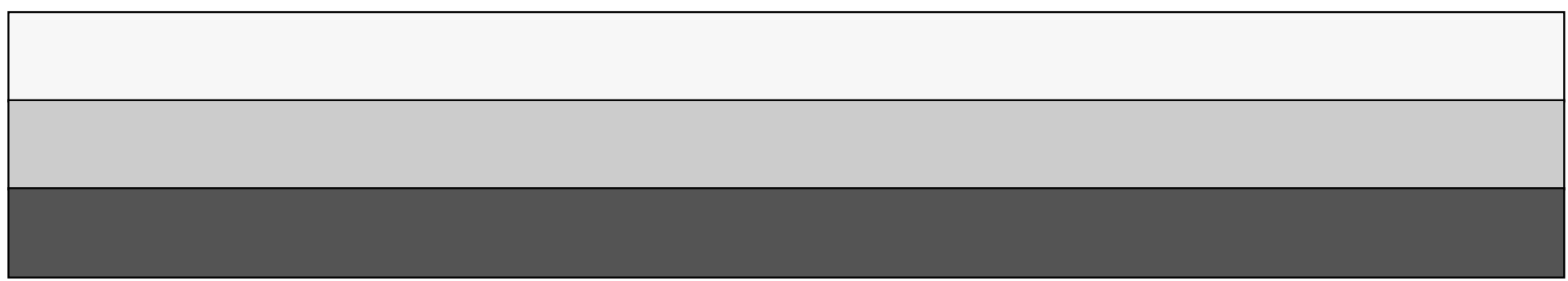

